\title{
Innovation in Health Services alignment with the Competitive Advantage Achievement in Private Hospitals in Saudi Arabia: Strategic Evidence
}

\author{
Dr. Mohammed Sultan Majied Mahasneh* \\ Dr. Saleh Abdulhabib Alnahdi* \\ Dr. Jehad S. Bani-Hani* \\ Dept. of Health Services and Hospital Management \\ Colleague of Business, University of Jeddah \\ Kingdom of Saudi Arabia \\ Dr. Mohammed Sultan Majied Mahasneh \\ Assistant professor in Health Services Administration \\ Dept. of Health Services and Hospital Management \\ University of Jeddah, Colleague of Business \\ Dr. Saleh Abdulhabib Alnahdi \\ Assistant professor in Healthcare Ethics \\ Dept. of Health Services and Hospital Management \\ University of Jeddah, Colleague of Business \\ Dr. Jehad S. Bani-Hani: Corresponding author \\ Associate professor in Business Administration \\ Dept. of Health Services and Hospital Management \\ University of Jeddah, Colleague of Business \\ Kingdom of Saudi Arabia-Jeddah P.O. Box: (80327)
}

\begin{abstract}
This study examines the extent that innovation in health services dimensions (product, and process) are aligned with competitive advantage within 40 private hospitals in Jeddah city (Kingdom of Saudi Arabia) listed in ministry of health in Saudi Arabia. The results of this study revealed a positive significant correlation between innovation and competitive advantage achievement. In addition, product innovation and process innovation emerged as the significant variables that affect competitive advantage achievement. This study contributes to a better understanding of the influence of innovation dimensions in competitive advantage achievement among private hospitals in Saudi Arabia.
\end{abstract}

Keywords:Innovation, Competitive Priorities, Health Sector. Hospitals in Saudi Arabia

\section{Introduction}

Modern organizations work in a highly competitive environment, which motivate them to seek new products (goods, services, and ideas), and processes to gain competitive advantage over other organizations in the same sector by adding value to clients and// or users and achieving excellence in a course that improves their competitive position.

The achievement of competitive advantage related to the perceived value of the customer, it means that the organization exploits the various capabilities to improve the value that the customer understands for the products and services provided by the organization,

Practically competitive advantage intended to meet the expectations, needs and desires related to the customer in order to acquisition of a good or service by customers (Stevenson, 2015). Competitive advantage seems that a direct relation between customers' expected values, values offered by the company, and those offered by the competitors determine the dimensions and conditions of competitive advantage. If the values presented by the company are closer to customers' expected values compared to the values offered by competitors, it can be said that the firm has competitive advantage over its competitors in one or more indices (Hosseini, Soltani, \&Mehdizadeh, 2018) 
In opposite, innovation seems as an evolving process in which new or significantly improved products or processes replace the existing ones, and must use the production and marketing technology to produce new product, attributes new products to consumers (Ganzer, Chais, \& Olea, 2017; Tidd, \& Bessant, 2009; Yasil, Koska, \& Buyukbese, 2015). Saudi private hospitals number is clearly growing, the number increased from 136 in 2013, to 158 at the end of 2017 (Annual Statistical Report, 2017). This growing number made hospitals to work in high competitive environment, which motivate them to investigate new opportunities to compete through finding necessary means and processes for introducing new health services, improving and developing current health services, and innovating new process design to introduce health services. To reach that, hospitals need to adopt the use of innovation; therefore, The purpose of this paper is to examine the existence connection between innovation in terms of product and process and competitive advantage achievement for hospitals in Saudi Arabia. The problem of this study lies in answering the following questions: (1) is there a statistically significant correlation between innovation (product and process) and achieving competitive advantage (cost, quality, flexibility, and delivery)? (2) Is there a statistically significant influence for innovation (product and process) in achieving competitive advantage (cost, quality, flexibility, and delivery)? To answer these questions, this study aims to: (1) Identify the innovation dimensions from Saudi private hospitals managers' point of view. (2) Identify the competitive advantage dimensions from Saudi private hospitals managers' point of view. (3) Investigate the correlation between innovation and competitive advantage from Saudi private hospitals managers' point of view, and (4) investigate the impact of innovation's dimensions in achieving competitive advantage from Saudi private hospitals managers' point of view.

\section{Literature Review}

\subsection{Innovation}

Many scholars have increasingly considered innovation after Schumpeter's study (1934). Innovation is a successful exploitation of ideas, commercial implementation of the best ideas, work methods and even business models for the organization. thus, becoming the most important component of the long-term economic growth engine (DTI, 2004; Alexiev, Volberda, \& Van, 2016), Innovation represent the ability of the organization to come up with something new that adds more value and faster and offer a new product better than the products of competitors in the market. Anahita, Jennifer \& Sally (2009), define innovation as the multi-stage process whereby organizations transform ideas into new/improved products, service or processes, in order to advance, compete and differentiate themselves successfully in their marketplace. Organizations can use innovation as leading force of competitiveness, growth, profitability and the creation of durable values (Fisk, 2008). The intensity of innovation is an explanatory factor of differences in economic performance between organizations, regions, and countries. Innovative organizations which record successes in innovation activities are prosperous at the expense of the more modest competitors involved in innovation (Mihaela, 2011). Innovation represent an integration of special assets, or resources of the firm, that comprises various assets such as technology, product, process, knowledge, and experience (Guan \& Ma, 2003; Karagouni \& Papadopoulos, 2007; Turker, 2012; Yam, Tang, \& Lau, 2010). Innovation capabilities were viewed as a comprehensive set of elements of a firm, which facilitates and supports its technological strategies in the business environment and successful use of these capabilities to sustain competitiveness performance for the firm (Burgelman, Christensen, \& Wheelwright, 2009). Organizations can use innovation process to achieve coordination and cooperation between the organization's functions (production, marketing and research and development). The role of innovation is pivotal for organizational performance as it can provide the organization with a sustainable competitive advantage and contribute to its long-term success (Bookis, 2016). Organizations adopt new ideas and methods and apply it in the field of work. Organizations can develop a new product (new good or service), and/ or develop an existing product (existing good or existing service),and/ or use a new production process, and/ or develop an existing production process to meet customer requirements of products \& services, as well as make the organization the best in the competition market (Petrariu, Bumbac \& Ciobanu, 2013).

Erturk (2009) indicated that the minimum requirement for an innovation is that the product, process, marketing method or organizational method must be new (or significantly improved) to the firm. This includes products, processes and methods that firms are the first to develop and those that have been adopted from other organizations. These theoretical approaches classify innovation in four categories; product and/or service innovation, process innovation, marketing innovation (competitive position), and organizational innovation (management or mental process), therefore, it is the result of strategic decisions taken by the organization through a newly developed business in order to provide a sustainable competitive advantage. OECD (2005) "Product innovation" and "process innovation" terms were used in Oslo Manual as dimensions of technological innovations. Product innovations is set as innovation that is used in a whole operations of the firm by which a new product and/ or service is created and marketed, and is conceived as an improvement of quality (Bacchiega, Lambertini, \& Mantovaini, 2011; Kuncoro \& Suriani, 2017). 
Product innovation is strengthen by the recruitment of new skills (Bocquet, 2011).Product/service innovation is related to changes in the products or services provided by an organization (Tidd et al., 2009)

Evans and Collier (2007) show that organizations focus on R \& D to achieve product innovation, which is an essential foundation of their strategy. Such organizations may be leaders in product technology as well as their ability to achieve product innovation and deliver new products are critical success factors. product innovation reflects the needs and wishes of customers and thus can lead to success and superiority of the organization over competitors (Dougherty \& Dunne, 2011). Product innovation is based on the strategy of excellence, so; the products have the right quality and the rest of the specifications for products produced by others. Product innovations involves introducing a new product/ service and improving existing product, and contributes in reducing production costs, time and improving products quality and makes products more competitive in home and external markets (Reguia, 2014)

On the other side, the process of innovation involves new ways of providing service with improved service delivery, (Chen \& Tsou, 2007), centered on improving the efficiency and effectiveness of the production process (Higgins, 1995), gain competitive benefits (Reichstein and Salter, 2006).

OECD (2005) stated that process innovations are usually aimed at decreasing costs of product/ service production or delivery, increasing quality, or producing or delivering new or improved products.

\subsection{Competitive Advantage}

For getting clear understanding for the competitive advantage. The concept needs to have comprehensive and more efficient definition. Competitive advantage is a position where an organization controls over a business competition arena (Kuncoro \& Suriani, 2018), reflected in the extent to which the organization is able to maintain and increase its market share in the environment or the area to which it belongs (Charles, Melissa \& Gareth, 2013). Competitive advantage lies in the properties or dimensions of each firm enabling it to offer better services than the competitors (i.e., better value) to customers (SaatyandVargas, 2012). Evans and Collier (2007) noted that competitive advantage is a declaration of the organization's ability to excel in marketing and finance above all its priorities. This requires understanding the overall framework of the organization, by identifying the customer's needs and desires. Thus contributing to building its competitive advantage. The value concept includes price, quality, and after-sale services. Competitive advantage is also linked to excellence, where can be achieved by offering a product or service that competitors cannot imitate or copy, some indicators which considered as used to measure competitive advantage are product uniqueness, product quality, and competitive price (Dirisu, Joe, \& Ibidunni, 2013).Four requirements should be met for resources and skills to be sources of sustainable competitive advantage: they should be valuable, rare in existing and potential competitors, not be easily imitable, and no strategic alternative for that skill or resource (Barney, 2001).

\subsubsection{Competitive Advantage Dimensions}

Li, Ragu-Nathan, Ragu-Nathan, \& Rao (2006), \& Thatte (2007) developed five dimensions to measure competitive advantage construct, namely price/cost, quality, delivery dependability, product innovation, and time to market. The most basic dimensions to achieve competitive advantage for the organization are cost, quality, flexibility and delivery of products (Davis, Aquilano, \& Chase, 2003; Dranove, Simon, \& White, 1999; Evans \& Collier, 2007; Ismail, Rose, Abdulah, \& Uli, 2010; Krajewsky, Malhotra, \& Ritzman, 2013; Sachitra, 2016; Slack, Chambures, Harland, Hareston, \& Johnstin, 2004; Stevenson, 2015).

\subsubsection{Cost Dimension}

Cost reduction is the most commonly dimension used by the organizations, especially those in markets where the customers are sensitive to prices (Diab, 2014). Organizations follow a lower cost strategy to achieve lower cost in their services to customers, thereby achieving competitive advantage across the sector. Organizations that seek to acquire a larger market share as a basis for their success and superiority are those who offer their products at a lower cost than their competitors do (Dangayach \& Deshmukh, 2006). Competing in the market based on cost is defined as a organization's ability to manufacture and distribute comparable products or services as competitors but at a lower cost (Drohomeretski, Gouvea, Pinheiro, Garbuio 2014; Peng, Schroeder, \& shah, 2011). The lowest cost is the main operational objective of organizations competing through cost, and even organizations that compete with other non-cost competitive (Slack, et al., 2004)

It clear that the organizations can achieve competitive advantage through reducing the costs of its products and services through efficient use of their production capacity. The factors that lead to lower costs; increased experience, qualifications, and education, successful investment, initiated suitable policies for production and distribution, and the exploitation of resources available. 


\subsubsection{Quality Dimension}

Quality is one of the main factors that have helped to raise the spirit of competition between organizations, because consumers have an awareness of the choice of high quality product or service at the right price. Organizations strive to achieve quality of services and products, which it's in turn, achieve the customer satisfaction and meet expectations through design quality of product and service, in addition to the quality of the service itself (Bakri and Salman, 2006). Many organizations work to achieve high quality improvement for their services or products in order to remain and continuous working in the competition market (Bani-Hani \& Al-Omari, 2012). Uses quality as a tool for competition requires organizations to consider the quality as the entrance to satisfy customers, not just as a way to solve problems and reduce costs (Baker, \& Crompton, 2000).

Porter (2008) defined quality as the process of creating and discovering new ways more effective than these used by competitors, and the ability of the organization to embody that discovery on the ground, in the sense of creating a widescale creative process. Quality is defined in more customer-focused ways as the ability of a organization to offer products and services that meet or exceed the expectations of customers (Alsmadi, Khan, \& Mctavish, 2011; Drake, Lee, \& Hssain, 2013; Jabbour , Maria, Paiva, Almada, 2012; Johansson \& Winroth, 2010). Quality is one of the key competitive priorities in the majority of papers included in the systematic literature review. Past researches indicated that product innovation had a significant impact on quality (Hu \& Huang, 2011; Ke-yi \& Qian, 2010; Nemati , Chatyipanagiotou, Vassilikopoulou, \& Siomkos, 2010; Stock, 2011).

\subsubsection{Flexibility Dimension}

Flexibility is the foundation for achieving the competitive advantage of the organization by responding quickly to changes that may occur in the design of products and services to suit the needs of customers. Flexibility means the organization's ability to change operations to other methods (Slack, et al., 2004). In operations, flexibility means having the capacity to adapt operations when necessary and respond quickly to changes in demand or needs of the production processes (Drohomeretski et al., 2014). The three sets of flexibilities include volume flexibility (Gray, Roth, \& Tomlin, 2009; Rebolledo \& Jobin, 2013), mix flexibility (Avella, \& Vazquz-Bustelo, 2011; Chi, 2010), design flexibility (Bolivar \& Espino, 2008; Dangayach \& Deshmukh, 2006).

\subsubsection{Delivery (Speed, Time) Dimension}

Delivery dimension is one of the key dimensions of organization competition in the markets by focusing on reducing deadlines, speeding up the design of new products and services, and delivering them to customers as soon as possible. The speed of service and response to customer demand has become one of the factors of competitions between organizations, this is linked to the customer's willingness to pay higher cost for the services or products he and $\backslash$ or she needs in a timely (Bakri, 2005). There are three priorities for the delivery dimension dealing with time: fast delivery, delivery on the exact time, speed of development. Evans and Collier (2007) show that time in today's society is one of the key sources of competitive advantage for the organization.

\section{Based on the previous literature review, the researchers extracted the main hypothesis as clarified below:}

HA1: There is a significant correlation between innovation and the dimensions of competitive advantage from hospitals managers' point of view, and the following sub-hypotheses emerge:

HA1a: There is a significant correlation between product innovation and the dimensions of competitive advantage from hospitals managers' point of view.

HA1b: There is a significant correlation between the process innovation and the dimensions of the competitive advantage from hospitals managers' point of view.

HA2: There is a significant impact of innovation in achieving competitive advantage from hospitals managers' point of view. The following sub-hypothesis emerge:

HA2a: There is a significant impact for product innovation in achieving competitive advantage from hospitals managers' point of view.

HA2b: There is a significant impact for process innovation in achieving competitive advantage from hospitals managers' point of view.

\section{Methodology}

\subsection{Population and Sample Research:}

The target population for this study comprised all the top managers working in private hospitals in Jeddah city, which include 40 hospitals (Minatory of health annual statistical book, 20017). A total number of (130) manager (Top, Middle, and lower level) were chosen randomly from the targeted population. 
We received 118 usable questionnaires indicating a response rate of $90 \%$. Focus on a single industry enables the researcher to better understand the processes and practices which facilitates comparison among firms (Tsikriktsis, 2007)

Table (1) indicates the individual's positionunder the study. It was found that the top management represented (24.6.1\%) while the middle management and the lower management of the health organizations under the study constituted (75.4\%) of the members of the research sample. The indicator of the individual's positionunder the study indicates that they were from different administrative levels. This is a good indication; it indicates that the questionnaire included all administrative levels. The opinions of managers at various administrative levels were obtained.

Table (2) shows that (100\%) of the individuals under the study are well qualified to understand and handle the components of the questionnaire properly.-

Table (3) shows that (33.1\%) of respondents have experience of more than (10) years in the health organizations under the study, so; managers gain knowledge and experience in their field, and qualify them to deal with the obstacles they face and make appropriate decisions..

\subsection{Research Theoretical Model:}

The researchers designed a model that reflects the correlation relationship and its impact between dimensions of technical innovation and the dimensions of competitive advantage. As shown in Figure 1

\subsection{Research Method}

Primary Data: Refereed Questionnaire was designed to measure the study variables. The questionnaire consist of three parts. The first part: includes Demographic Data that describe the study sample respondents, the second part: includes two sections to measure the study variables, the first one to measure technical innovation variables, and the second one to measure competitive advantage. Likert 5 scale used to The questionnaire was prepared in light of the scientific vision achieved through the survey of scientific sources related to the subject of research. The study variables were derived from several studies as (Ganzer, et al., 2017; Ionescu, Dumitru, \& Rossela, 2015; Kuncoro, \& Suriani, 2017; Panigrahy, \& Pradhan, 2015; Sachitra, 2016; Yasil, \& Buyukbese, 2015; Yusof, Roddin, \& Awang, 2015), Secondary Data: Periodicals, dissertations, theses, and the Internet, which are related to the research subject to cover the theoretical side of the research and support the field side.

\subsection{Empirical validation and reliability}

To ensure the content validity of the instrument tool, it has been developed based on extensive review of the literature, and scholars and practitioners from Saudi universities have reviewed it. The referees displayed their constructive comments and suggestions, which were taken into consideration. The reliability test measure indicates the extent to which is conducted without bias (error free) and ensures the consistency of measurement across time and across the various items in the instrument. In other words, the reliability of measurement is an indication of the stability and internal consistency with which the instrument measures the concept and helps to assess "the goodness" of a measure. The reliability of data collected instrument was measured using Cronbach's alpha coefficient; the reliability test was conducted to check for inter-item correlation in each of the variables in the questionnaire. The closer Cronbach's alpha is to one, the higher the internal consistency reliability (Sekaran, 2010). The test results are as follows: Cronbach's alpha for Innovation factors 0.91 , Cronbach's alpha for competitive advantage $=0.88$, Cronbach alpha for over all instruments $=0.90$, which approached to the acceptable limit.

\section{Results \& Discussions}

\subsection{Results Description}

The mean and standard deviation of the study variables related to study variables are summarized in table (4). Results show that innovation is considered as an important factor from hospitals managers poin of view, and it appeared as follow: Process innovation mean (3.97), product innovation mean (3.89). The standard deviation lies between (0.790.94), this indicates more concentrated, or homogeneous the data and less spread out or dispersed.

As for dependent variable, which is competitive advantage, the results shows that competitive advantage dimensions had relatively high scores of mean as follow: cost (4.66), quality (4.54), flexibility (4.47), and delivery (4.61). These results are similar to those of the relevant studies in the literature (Uyar and Oralhan, 2017). The standard deviation lies between (0.74-0.87), this indicates homogeneous data and less spread out or dispersed. 


\subsection{Hypotheses Testing}

The hypotheses of this study are aimed to examine the relationship between innovation factors and competitive advantage dimensions on one hand, and on the other hand to examine the impact of innovation factors in competitive advantage dimensions

\subsubsection{Innovation - Competitive Advantage Correlation}

Table (5) shows that there is a significant positive correlation between the innovation and competitive advantage, the total Indicator of correlation coefficients (0.775), which implies that the higher the private hospitals in Saudi Arabia interested in maximizing its efforts in innovation, the higher the opportunity to achieve high levels of competitive advantage.

The findings appeared that there is a significant correlation between product innovation and competitive advantage; this implies that whenever private hospitals increased its interest in improving its services and creating new services, the opportunity of achieving competitive advantage will increase. The correlation coefficient is $(0.731)$. This result is consistent with (Kariuki, 2017; Beaudreau, 2016; Wanjiku, 2018; Wanyoike, 2016).

Table (5) shows that there is a significant correlation between the product innovation and the cost dimension $(\mathrm{R}=$ $0.520)$, significant correlation between product innovation and quality dimension $(R=0.676)$, significant correlation between the product innovation and flexibility dimension $(\mathrm{R}=0.538)$. Finally, there is a significant correlation between product innovation and delivery dimension $(\mathrm{R}=0.547)$. These results are consistent with (Berry et al., 2006; Hu \& Huang, 2011; Ke-yi, \& Qian, 2010, Nemati et al., 2010; Reguia, 2014; Stock, 2011).

Based on the above, the first sub-hypothesis derived from the first hypothesis is accepted, which states that, there is a significant correlation between product innovation and the dimensions of competitive advantage combined.

Results as appeared in Table (5) show a positive correlation between the process innovation and competitive advantage. The correlation coefficients is $(0.675)$ this implies that whenever private hospitals increased its interest in improving its mechanisms of providing the health services for users and increasing the Intrapreneurship within the hospital, the opportunity of achieving competitive advantage will increase. These results are consistent with (Herrera, 2015; Kariuki, 2017; Wanjiku, 2018; Wanyoike, 2016). The results show a significant correlation between process innovation and cost dimension $(\mathrm{R}=0.448)$, significant correlation between process innovation and quality dimension $(\mathrm{R}=0.575)$, significant correlation between process innovation and flexibility dimension $(\mathrm{R}=0.530)$, and a significant correlation between the process innovation and delivery dimension $(\mathrm{R}=0.531)$. These results are consistent with the views of Noorani (2014) and OECD (2005).

Based on the above, the second sub-hypothesis arising from the first hypothesis is accepted, which states that, there is a significant correlation between the process innovation and the dimensions of the competitive advantage combined.

\subsubsection{Influence of Innovation in Competitive Advantage}

Multiple regression analysis was conducted to test the hypotheses. Multiple regression identifies how much of the variance in the dependent variable (Competitive Advantage) will be explained when a set of variables is able to predict a particular outcome. Table (6) shows that there is a significant impact for innovation in achieving competitive advantage.

Table 6 shows the results of a multiple regression analysis on competitive advantage. After running a regression analysis, product and process innovation emerged as the significant variables.

From the coefficient of determination $\mathrm{R}^{2}$ of the regression path: Product Innovation - Competitive Advantage, it can be seen that Product Innovation interpreted the highest percent $(73 \%)$ of the total variance in competitive advantage achievement. (H2a) sub-hypothesis was confirmed as a positive $(\beta=0.731)$ significant $(\mathrm{P}<0.05)$ impact for product innovation in competitive advantage achievement.

A higher-but not the highest- percent $(67.5 \%)$ of the total variance in competitive advantage achievement was interpreted by Process Innovation as can be seen from the coefficient of determination $\mathrm{R}^{2}$ of the regression path: Process Innovation -Competitive Advantage. $(\mathrm{H} 2 \mathrm{~b})$ sub-hypothesis was confirmed as a positive $(\beta=0.675)$ significant $(\mathrm{P}<0.05)$ impact process innovation in competitive advantage achievement. These results are consistent with (Hana, 2013; Nuryakin, 2018; Zainurossalamia, 2016).

\section{Conclusions}

After analyzing the data and testing the hypotheses, the following major conclusions were reached, (1) Results show that $30 \%$ of the respondents have an actual experience for more than 10 years. 
During that period, they acquire the experience and knowledge, which support them to engage in innovation activities that can achieve competitive advantage. (2) Results show that $77 \%$ of the respondents are scientifically qualified, which enable them to implement the work related to innovation efficiently. (3) Innovation Dimensions (Product and Process) are appeared in high percentages with a mean $(3.89,3.97)$ receptively, while competitive advantage dimensions, appeared with relatively high means. (4) There is a strong positive significant correlation at ( $\mathrm{P} \square 0.05$ ) betveen Innovation (Product and Process) and Competitive Advantage achievement, which implies that the higher the private hospitals in Saudi Arabia interested in supporting its innovation activities, the higher the opportunity to achieve high levels of competitive advantage. (5) Results show a significant impact for Innovation (Product and Process) in Competitive Advantage achievement,

\section{Recommendations \& Suggestions}

1. Spread the innovation culture within private hospitals managers through conducting lectures, courses, training workshops and participation in conferences in cooperation with Saudi universities.

2. The Saudi private hospitals are highly encouraged to adopt innovation as a strategy to improve that may leads to achieve considerable advantage.

3. Top managers of the Saudi private hospitals are invited to use several dimensions of innovation in planning, setting, and achieving the competitive strategies. Through encourage employees to provide creative and achievable ideas in the fields of product innovation and process innovation

4. Health organization management should focuses on technical innovation as a key tool to help them to introduce new services, improve existing services, design new processes, and improve existing processes to adapt to the outputs of technological development and market competition.

\section{References}

Alexiev, A. S., Volberda, H. W. \& Van den Bosch, F. A. (2016). Inter organizational collaboration and firm innovativeness: Unpacking the role of the organizational environment. Journal of Business Research, 69(2), 974-984.

Alsmadi, M., Khan, Z., McTavish, A.-M. (2011). Evaluating competitive advantage priorities of SMEs in Jordan. International Journal of Networking and Virtual Organizations 9(1): 25-43.

Anahita B., Jennifer R., \& Sally S. (2009). Towards a Multidisciplinary Definition of Innovation, Management Decision 47(8).

Avella, L. \& Vázquez-Bustelo, D. (2010). The multidimensional nature of production competence and additional evidence of its impact on business performance. International Journal of Operations and Production Management 30(6): 548-583.

Avella, L., Vazquez-Bustelo, D., Fernandez, E. (2011). "Cumulative manufacturing capabilities: An extended model and new empirical evidence. International Journal of Production Research 49(3): 707-729.

Bacchiega, E., Lambertini, L., \& Mantovaini, A. (2011). Process and product innovation in a vertically differentiated industry. International Game Theory Review, 13(2), 209-221.

Baker, Dwayne A., \& Crompton, John L. (2000). Quality, Satisfaction and Behavioral Intentions, Annals of Tourism Research, 27( 3), 785 \pm 804 .

Bani Hani, Jehad S. \& Al-Omari, Zyad (2012). The Role of Quality Improvement Factors in Improving Quality Based Operational Performance: Applied Study in Private Hospitals in Jordan, International Journal of Business and Social Science, 3(18), 213-222

Barney, Jay B. (2001). Resource-based theories of competitive advantage: A ten-year retrospective on the resourcebased view, Journal of Management, 27(6), 643-650.

Beaudreau, B. C. (2016). Competitive and Comparative Advantage:Towards a Unified Theory of International Trade, International Economic Journal, 30(1), 1-18.

Berry, L.L., Shankar, V., Parish, J.T., Cadwallader, S. \& Dotzel, T. (2006). Creating new markets through service innovation. Sloan Management Review, 47(2), 56- 63.

Bocquet, R. (2011). Product and process innovations in subcontracting: Empirical evidence from the French 'Sillon Alpin'. Industry and Innovation, 18(7), 649-668.

Bolivar C. \& Espino R. (2008). "An analysis of operations strategy in the food and beverage sector." International Journal of Services and Operations Management 4(1): 102-124.

Bookis, Achilleas (2016). Managing Innovation within Organizations. In Goel, Alo Kumar \& Singhal, Puja (Eds.), Product Innovation through Knowledge Management and Social Media Strategies. Business Science Reference. 
Burgelman, Robert A., Christensen, Clayton M., \& Wheelwright, Steven C. (2009). Strategic Management of Technology and Innovation, $5^{\text {th }}$ ed., Boston, McGraw-Hill Irwin.

Charles W. L., Melissa A. \& Gareth R. (2013), Strategic Management: An Integrated Approach, 10th edition, U.S.A. Erin Joyner, ISBN: 978-1-133-48571-1.

Chen, J. S. \& Tsou, H. T. (2007). Information Technology adoption for services innovation practices and competitive advantage: the case of financial firms. Information research: an international electronic journal, 12(3), 314. Retrieved February 15, 2019 from: Http//InformationR.net/

Chi, T. (2010). Corporate competitive strategies in a transitional manufacturing industry: An empirical study. Management Decision 48(6): 976-995.

Dangayach, G. S. \& Deshmukh, S. G. (2006). An exploratory study of manufacturing strategy practices of machinery manufacturing companies in India. Omega 34(3): 254-273.

Davis, M. ,M.; Aquilano, N. J. \& Chase, R. B. (2003). Fundamentals of Operations Management . 4th ed., U.S.A, Mc Graw- Hill Companies.

Diab, Salah M. (2014). Using the Competitive Dimensions to Achieve Competitive Advantage A Study on Jordanian Private Hospitals, International Journal of Academic Research in Business and Social Sciences, 4(9). 138-150

Dirisu, I., Joy, Iyiola, O., \& Ibidunni, S. O. (2013). Product differentiation: A tool of competitive advantage and optimal organizational performance (a study of unilever Nigeria plc). European Scientific Journal, 9(34).

Doughert, Deborah \& Dunne, Danielle D., (2011). Organizing Ecologies of Complex Innovation, Organization Science 22(5), 1214-122.

Drake, P. R., Lee, D. M., Hussain, M. (2013). "The lean and agile purchasing portfolio model." Supply Chain Management 18(1): 3-20.

Dranove, David, Simon, Carol, \& White, William D. (1999). The Determinants of Managed Care Penetration, Journal of Health Economics, 17(6):729-45

Drohomeretski, E., Gouvea Da Costa, S. E., Pinheiro De Lima, E., Garbuio, P. A. D. R. (2014). Lean, six sigma and lean six sigma: An analysis based on operations strategy. International Journal of Production Research 52(3): 804-824.

DTI (2004) Succeeding Through innovation, Creating Competitive Advantage through Innovation: A Guide for Small and Medium Sized Businesses, Department of Trade and Industry, London.

ERTÜRK, M., (2009). The Role of Technological Innovation in the Firm. Journal of Global Strategic Management,3(2), 209-226.

Evans and Collier (2007). Operations Management an Integrated Goods and services approach, international student edition, U.S.A,South western, Thomson, 124-126.

Fisk, P. (2008), Business Genius, Editura Meteor Press.

Ganzer, P. P. ; Chais, C.; \& Olea, P. M. (2017). Product, process, marketing and organizational innovation in industries of the flat knitting sector. RAI Revista de Administração e Inovação 14 (2017) 321-332. Retreived March 11, 2019, from www.sciencedirect.com.

Gray, J. V., Roth, A. V., Tomlin, B. (2009). The influence of cost and quality priorities on the propensity to outsource production. Decision Sciences 40(4): 697-726.

Guan, J. \& Ma, N. (2003). Innovative capability and export performance of Chinese firms. Technovation, 23(9), 737747.

Hana, Urbancová (2013). Competitive Advantage Achievement through Innovation and Knowledge, Journal of Competitiveness, 3(1), 82-96.

Herrera, M. E. (2015). Creating competitive advantage by institutionalizing corporate social innovation. Journal of Business Research, 68(7), 1468-1474.

Higgins, J. M. (1995). Innovate or evaporate: Test \& improve your organization's IQ: Its innovation quotient. New Management.

Hosseini, Akram Sadat; Soltani, Sanaz; \& Mehdizadeh, Mohammad (2018). Competitive Advantage and Its Impact on New Product Development Strategy (Case Study: Toos Nirro Technical Firm), Journal of Open Innovation; Technology, Market, and Complex.

Hu, Y., \& Huang, X. (2011). Key service drivers for high-tech service brand equity: The mediating role of overall service quality and perceived value. Journal of Marketing Management, 27(1/2), 77-97.

Ionescu, A., Dumitru, N. Rossela, (2015), The Role of Innovation in Creating the Competitive advantage, Ecoforum, 4 (6), 118.

Ismail A.I., Rose R.C., Abdullah H., Uli J. (2010). The Relationship between Organizational Competitive Advantage and Performance Moderated by the Age and Size of Firms. Asian Academy of Management Journal, 15 (2), 157-173. 
Jabbour, C. J. C., Maria Da Silva, E., Paiva, E. L., Almada Santos, F. C. (2012). Environmental management in Brazil: Is it a completely competitive priority? Journal of Cleaner Production 21(1), 11-22.

Johansson, G. \& Winroth, M. (2010). Introducing Environmental concern in manufacturing strategies: Implications for the decision criteria, Management Research Review, 33(9), 877-899.

Karagouni, G. \& Papadopoulos, I. (2007). The impact of technological innovation capabilities on the competitiveness of a mature industry. Management of International Business \& Economic Systems, 1(1), 17-34.

Kariuki, A. N. (2017). Effects of Innovation Strategy in Enhancing Competitive Advantage among Commercial Banks in Kenya, (Unpublished doctoral dissertation). United States International University-Africa, Nairobi, Kenya.

Ke-yi, W., \& Qian, M. (2010). An Empirical Investigation of Product Innovation and Customer Loyalty in Telecommunication Industry. Journal of Business Research, 64, 1234-1238.

Krajewski, L. J., Malhotr, M. K. \& Ritzman, L. P. (2015). Operations Management: Processes and Supply Chain, $11^{\text {th }}$ ed., Pearson.

Kuncoro W., Suriani W. O., (2017). Achieving sustainable competitive advantage through product innovation and market driving, Asia Pacific Management Review, 1-7.

Li. S., Ragu-Nathan, B., R.; Ragu-Nathan, T.S. and Rao, S.S. (2006). The impact of supply chain management practices on competitive advantage and organizational performance. Omega. 34:107-124.

Mihaela D., (2011), Technological Innovation: Concept, Process, Typology and Implications in the Economy, Theoretical and Applied Economics Journal, 10(563), 127-144.

Ministry of Health (2017). Annual Statistical Book, Retrieved April 13, 2018, from www.moh.gov.sa/

Nemati, A., Chatyipanagiotou, K.; Vassilikopoulou, A. \& Siomkos, G. (2010). Impact of Innovation on Customer Satisfaction and Brand Loyalty, A Study of Mobile Phones Users in Pakistan. European Journal of Social Success. 16 (4), 285-297.

Noorani, Ibrahim (2014). Service Innovation and Competitive Advantage. European Journal of Business and Innovation Research,2 (1), 12-38.

Nuryakin (2018). Competitive Advantage and Product Innovation: Key Success of Batik SMEs Marketing Performance in Indonesia, Academy of Strategic Management Journal. 17(2).

OECD (2005). Oslo Manual: Guidelines for Collecting and Interpreting Innovation Data.

Peng, D. X., Schroeder, R. G., Shah R. (2011). Competitive priorities, plant improvement and innovation capabilities, and operational performance, International Journal of Operations and Production Management, 31(5), 484510.

Petrariu, I.R, Bumbac, R., Ciobanu, R. (2013). Innovation: a path to competitiveness and economic growth. The case of CEE countries, Theoretical and Applied Economics, 5 (582),15-26

Porter, M. E. (2008). The Five Competitive Forces that Shape Strategy. Harvard Business Reviews, 27(5). Retrieved December 17, 2018, from http://mktgsensei.com/

Rebolledo, C. \& Jobin, M. H. (2013). Manufacturing and supply alignment: Are different manufacturing strategies linked to different purchasing practices? International Journal of Production Economics 146(1): 219-226.

Reguia, Cherroun (2014). Product Innovation and Competitive Advantage. European Scientific Journal, 1.

Reichstein, T. \& Salter, A., (2006). Investigating the sources of process innovation among UK manufacturing firms. Industrial and Corporate Change, 15(4), 653-682.

Saaty, T.L. and Vargas, L.G. (2012) Models, Methods, Concepts \& Applications of the Analytic Hierarchy Process. New York, Springer Science \& Business Media.

Sachitra, Vilani (2016). Review of Competitive Advantage Measurements: Reference on Agribusiness Sector. Journal of Scientific Research \& Reports 12(6): 1-11.

Sekaran, Uma (2010). Research Methods for Business: A Skill-Buildings Approach. (5th ed.), New York: John Wiley $\&$ Sons Inc.

Slack, N.; Chambers, S.; Harland, C.; Harrston, A; \& Johnston, R. (2004). Operations Management. $4^{\text {th }}$ ed., New York, Prentice Hall:. 44-45.

Stevenson, W. J. (2015). Operations Management Theory and Practice, $12^{\text {th }}$ ed., NY: McGraw-Hill/Irwin.

Stock, R. M. (2011). How does product program innovativeness affect customer satisfaction? A comparison of goods and services. Journal of the Academy of Marketing Science, 39, 813-827.

Thatte A. A. (2007). Competitive advantage of a firm through supply chain responsiveness and SCM practices, (Unpublished doctoral dissertation). The University of Toledo.Rereavyd December 17, 2018, from http://202.154.59.182/ejournal/fil es/thatte_a_-_competitive_advanta.pdf.

Tidd, Joe. \& Bessant, John. (2009). Managing innovation: Integrating technological, market and organizational change. $4^{\text {th }}$ ed., John Wiley \& Sons, 
Turker, M. V, (2012). A model proposal oriented to measure technological innovation capabilities of business firms - a research on automotive industry. Procedia - Social and Behavioral Sciences 41, 147 - 159.

Uyar, Kumru \& Oralhan, Burcu (2017). Innovation Capability and Export Performance of Turkish Export Firms, Chinese Business Review, 16(10), 481-495

Wanjiku, ESTHER MUTHONI (2018). The Effect of Innovation on Sustainable Competitive Advantage (client Satisfaction) in the Hospitality Industry in Kenya a Case Study of Safari Park Hotel. (Unpublished Master Thesis). United States International University-Africa.

Wanyoike, M. P. (2016). Relationship between Innovation Strategies and Competitive Advantage in the Logistics Firms in Mombasa Country, Kenya, (Unpublished Master Thesis).University of Nirobi..

Yam, R. C., Lo, W., Tang, E. P. \& Lau, K. W. (2010). Technological innovation capabilities and firm performance. World Academy of Science, Engineering and Technology, 42, 1009-1017.

Yasil, S., Koska, A., \& Buyukbese, T. (2015). Knowledge sharing process, innovation capability and innovation Performance: An empirical study, 2nd International Conference on Leadership, Technology and Innovation Management. Procedia - Social and Behavioral Sciences, 75,217-225.

Yusof, Y., Roddin, R., \& Awang, H. (2015). What Students Need, and What Teacher Did: The Impact of Teacher's Teaching Approaches to the Development of Students' Generic Competences. Procedia Social and Behavioral Sciences, 204, 36-44.

Zainurossalamia, S. et al. (2016). The Effect of Innovation on Firm Performance and Competitive Advantage. European Journal of Business and Management. 8(29).

Table (1) Individuals Position

\begin{tabular}{|c|c|c|c|c|c|}
\hline \multicolumn{2}{|c|}{ Top Level Management } & \multicolumn{2}{c|}{ Middle Level Management } & \multicolumn{2}{c|}{ Lower Level Management } \\
\hline Number & $\mathbf{\%}$ & Number & $\mathbf{\%}$ & Number & $\%$ \\
\hline 29 & 24.6 & 45 & 38.1 & 44 & 37.3 \\
\hline
\end{tabular}

Table (2) Academic Qualification

\begin{tabular}{|c|c|c|c|c|c|}
\hline \multicolumn{2}{|c|}{ Postgraduate } & \multicolumn{2}{c|}{ Bachelor } & \multicolumn{2}{c|}{ Diploma } \\
\hline Number & $\mathbf{\%}$ & Number & $\mathbf{\%}$ & Number & $\%$ \\
\hline 38 & 32.2 & 53 & 44.9 & 27 & 22.9 \\
\hline
\end{tabular}

Table (3) Experience (year)

\begin{tabular}{|c|c|c|c|c|c|}
\hline \multicolumn{2}{|c|}{ Less than 10} & \multicolumn{2}{c|}{ 10-Less than 20 } & \multicolumn{2}{c|}{20 and more } \\
\hline$\%$ & Number & $\%$ & Number & $\%$ & Number \\
\hline
\end{tabular}

Figure (1) The Default Research Model. (Researchers)

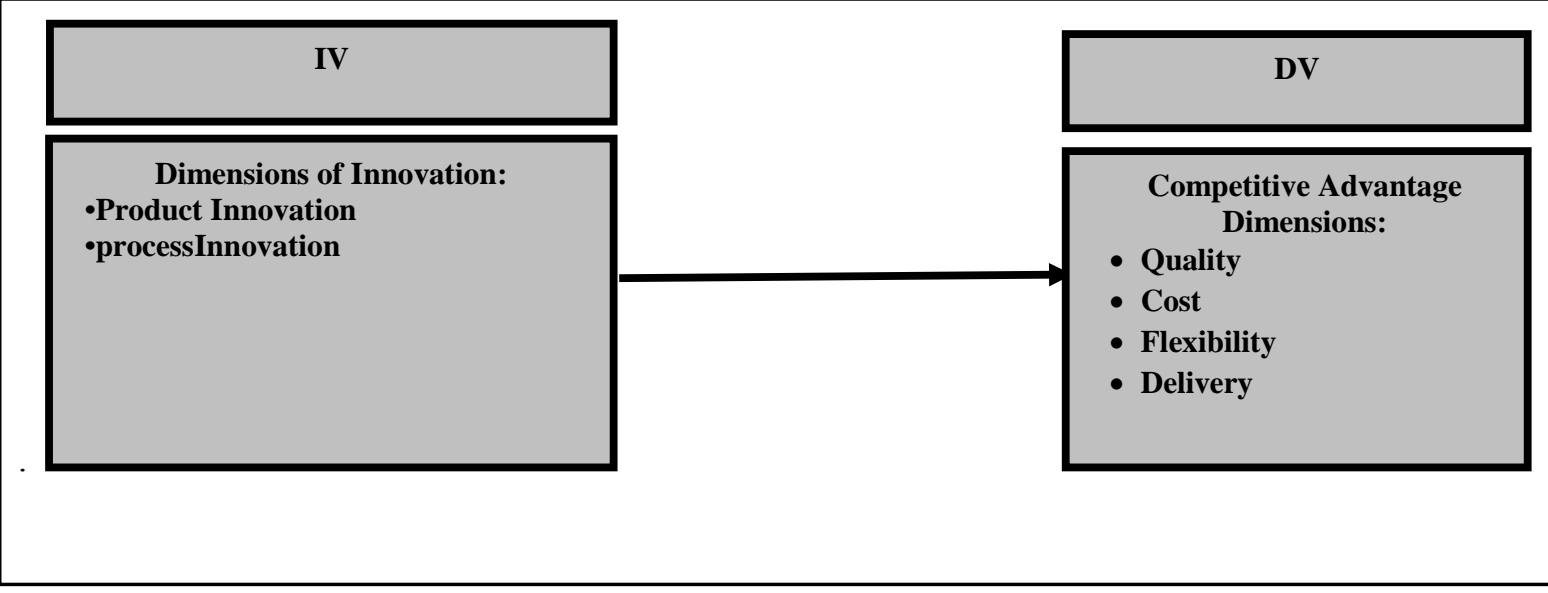


Table 2: Descriptive results for study variables

\begin{tabular}{|c|c|c|}
\hline Variables & Mean & Std. \\
\hline \multicolumn{3}{|c|}{ Independent Variables (Innovation) } \\
\hline 1. Product & 3.89 & 0.94 \\
\hline 2. Process & 3.97 & 0.79 \\
\hline \multicolumn{3}{|c|}{ Dependent Variables (Competitive Advantage) } \\
\hline Cost & 4.66 & 0,77 \\
\hline Quality & 4.54 & 0.81 \\
\hline Flexibility & 4.47 & 0.87 \\
\hline Delivery & 4.61 & 0.74 \\
\hline
\end{tabular}

Table (5) Correlation coefficients ( $R$ value) between Innovation and Competitive Advantage

\begin{tabular}{|c|c|c|c|c|c|c|}
\hline \multirow{2}{*}{\multicolumn{2}{|c|}{$\begin{array}{l}\text { Dependent variable } \\
\text { Independent variable }\end{array}$}} & \multicolumn{4}{|c|}{ Competitive Advantage Dimensions } & \multirow{2}{*}{$\begin{array}{c}\text { Total } \\
\text { Indicator }\end{array}$} \\
\hline & & Cost & Quality & Flexibility & delivery & \\
\hline \multirow{2}{*}{$\begin{array}{l}\text { Dimensions of } \\
\text { Innovation }\end{array}$} & Product Innovation & $0.520 *$ & $0.676 *$ & 0.538* & $0.547 *$ & $0.731 *$ \\
\hline & Process innovation & $0.448 *$ & $0.575^{*}$ & $0.530 *$ & $0.531 *$ & $0.675^{*}$ \\
\hline \multicolumn{6}{|c|}{ Total Indicator } & $0.775^{*}$ \\
\hline
\end{tabular}

$\mathrm{p} \leq 0.05 \mathrm{~N}=118$

Table (6) Influence of Innovation in Competitive Advantage

\begin{tabular}{|c|c|c|c|c|c|}
\hline Competitive Advantage & $\beta$ & $\beta$ Sig. & $\mathrm{R}^{2}$ & $\begin{array}{c}\text { Standard } \\
\text { Error }\end{array}$ & Sig. \\
\hline Product & 0.731 & 0.00 & 0.534 & 0.132 & 0.00 \\
\hline Process & 0.675 & 0.00 & 0.456 & 0.112 & 0.00 \\
\hline
\end{tabular}

$p \leq 0.05 \mathrm{~N}=118$ 